\title{
Effective Preemergence Herbicides for Rigid Ryegrass (Lolium rigidum Gaud.) Control in Irrigated Bread Wheat (Triticum aestivum L.)
}

\author{
Abbès Tanji ${ }^{1} \&$ Mohamed Boutfirass ${ }^{2}$ \\ ${ }^{1}$ Retired Weed Scientist, Settat, Morocco \\ ${ }^{2}$ Institut National de la Recherche Agronomique, Settat, Morocco \\ Correspondence: Abbès Tanji, Retired Weed Scientist, Farah 1, Rue Kacem Amine No. 1, Settat 26002, Morocco. \\ E-mail: abbestanji1@gmail.com
}

$\begin{aligned} & \text { Received: November 17, } 2017 \\ & \text { Accepted: February 10, } 2018 \quad \text { Online Published: March 15, } 2018 \\ & \text { doi:10.5539/jas.v10n4p79 }\end{aligned}$ URL: https://doi.org/10.5539/jas.v10n4p79

This research work was conducted under the project "Enhancing Food Security in Arab Countries-Phase II". The authors would like to thank the Arab Fund for Economic and Social Development (AFESD), the Kuwait Fund for Arab Economic Development (KFAED), the Bill and Melinda Gates Foundation (BMFG) and the OPEC Fund for International Development (OFID) for their financial support and ICARDA for facilitating this study.

\begin{abstract}
Three on-farm weed control experiments were conducted in irrigated bread wheat in the Doukkala perimeter, Morocco, in 2015-16 and 2016-17 in order to study the efficacy of 4 pre-emergence herbicide treatments for controlling rigid ryegrass that is resistant to 13 post-emergence herbicides. Results showed that 3 pre-emergence herbicides [i) chlorotoluron, $2000 \mathrm{~g} / \mathrm{ha}+$ isoxaben, $74.8 \mathrm{~g} / \mathrm{ha}$; ii) prosulfocarb, $4000 \mathrm{~g} / \mathrm{ha}$; iii) prosulfocarb, 2000 $\mathrm{g} / \mathrm{ha}+\mathrm{s}$-metolachlor, $300 \mathrm{~g} / \mathrm{ha}$ ] reduced rigid ryegrass shoot biomass by $>90 \% 1$ to 3 months after treatments (MAT). Pendimethalin (1320 $\mathrm{g} \mathrm{ha}^{-1}$ ) achieved 83-99\% rigid ryegrass control 1 to 3 MAT. The four herbicide treatments were safe on wheat in one experiment, but reduced wheat density in 2 other experiments due to heavy rain (about $100 \mathrm{~mm}$ ) after herbicide treatments and before crop emergence. Grain yields in sprayed plots ranged from 6.6 to $9.8 \mathrm{tha}^{-1}, 4.4$ to $7.4 \mathrm{t} \mathrm{ha}^{-1}, 7.3$ to $8.9 \mathrm{t} \mathrm{ha}^{-1}$ in experiments 1 to 3 , respectively. Straw yields were 11.4 to $15.4,9.6$ to 15.8 , and 10.1 to $14.5 \mathrm{t} \mathrm{ha}^{-1}$ in the 3 experiments, respectively. These preemergence herbicides need to be used by wheat growers as part of an integrated weed management program. Further research is needed to explore ways to avoid wheat injury, that could be occasionally caused by heavy rain or irrigation, after preemergence herbicide application and before crop emergence.
\end{abstract}

Keywords: rigid ryegrass, Lolium rigidum, preemergence herbicides, resistance to herbicides, irrigated wheat

\section{Introduction}

Because of over reliance on herbicides, rigid ryegrass (Lolium rigidum Gaud.) has evolved resistance to 13 different herbicide mode of action groups in 12 countries (Heap, 2018). It is the first example of a weed that demonstrated multiple resistance to many herbicide families, including aryloxyphenoxyproprionates, cyclohexanediones, sulfonylureas, and others. The patterns of resistance are variable, reflecting the genetic diversity of the species and the management practices imposed. Resistance in rigid ryegrass is one of the most economically important examples of herbicide resistance in world agriculture. The mechanisms of resistance in rigid ryegrass have been demonstrated to be i) target site mutations within ACCase (acetyl coenzyme A carboxylase) and ALS (acetolactate synthase) and ii) enhanced herbicide metabolism of ACCase-, ALS-, and PS II-inhibiting herbicides (Délye, 2005; Scarabel et al., 2011; Malone et al., 2014; Yu \& Powles, 2014; Saini et al., 2015; Han et al., 2016; Loureiro et al., 2017).

Rigid ryegrass has many features that contribute to the evolution of resistance, including i) a very well adapted species to the Mediterranean climate, ii) a propensity to occur in large densities, iii) the high genetic diversity within populations, iv) a self-incompatibility and cross-pollinated species, v) the potential to set a large amount 
of seed, allowing any resistant survivors to significantly increase the resistance status of a population, vi) the short-lived innate dormancy, which results in a large amount of the seedbank germinating in the next season, vii) the short soil seedbank life, and viii) the ability to rapidly evolve resistance to herbicides (Castellanos-Frias et al., 2016; Bararpour et al., 2017).

In Morocco, rigid ryegrass has infested Tadla irrigated perimeter since 2010 (Baye, 2014) and Doukkala since 2000 (Tanji, 2009, 2011, 2013; Tanji et al., 2012; El Aimani \& Tanji, 2016). Rigid ryegrass is now resistant to 13 herbicides ( 7 wheat herbicides: clodinafop, diclofop, fenoxaprop, mesosulfuron, pinoxaden, pyroxsulam, and tralkoxydim, and 6 sugar beet (and other broadleaf crops) herbicides: cycloxydim, fluazifop, haloxyfop, propaquizafop, quizalofop, and tepraloxydim). All these herbicides that are no longer effective on rigid ryegrass have two modes of action: inhibition of acetyl coenzyme A carboxylase (ACCase) (group A) such as clodinafop, cycloxydim, diclofop, fenoxaprop, fluazifop, haloxyfop, pinoxaden, propaquizafop, quizalofop, tepraloxydim, and tralkoxydim, and inhibition of acetolactate synthase (ALS) (group B) such as mesosulfuron and pyroxsulam. Temporarily, clethodim has the ability to control rigid ryegrass populations having resistance to other ACCase-inhibiting herbicides (Tanji, 2013).

With the ineffectiveness of post-emergence herbicides on the herbicide-resistant rigid ryegrass, pre-emergence herbicides (prosulfocarb, s-metolachlor, and others) were registered in Australia, USA, Europe, and other countries for use in wheat (Negre et al., 2006; Chauhan et al., 2007; Boutsalis et al., 2014; Kleemann et al., 2014; Preston et al., 2017). In Morocco, there were recently registrations of pre-emergence herbicides (chlorotoluron, isoxaben, prosulfocarb, s-metolachlor, and others) that have provided an effective tool for control of multiple-herbicide-resistant rigid ryegrass populations. According to Heap (2018), Chlorotoluron belongs to the urea that inhibits photosynthesis at photosystem II (group C2). Isoxaben is a Benzamide that inhibits cell wall (cellulose) synthesis (group L). Pendimethalin is a dinitroaniline that inhibits microtubule assembly (group K1). Prosulfocarb is a herbicide belonging to the thiocarbamates (group N) which inhibits lipid synthesis without inhibiting acetyl coenzyme A carboxylase (ACCase). S-metolachlor is a chloroacetamide herbicide that inhibits cell division (group K3). All these herbicides are able to control emerging rigid ryegrass and other weeds when applied preemergence in wheat and other crops. The objective of this paper is to present results on the efficacy of 4 preemergence herbicide treatments on rigid ryegrass that has evolved resistance to several postemergence herbicides.

\section{Materials and Methods}

\subsection{Experiment Site and Design}

Three on-farm weed control experiments were conducted in the Doukkala irrigated perimeter, Morocco: experiment 1 in 2015-16 and experiments 2 and 3 in 2016-17. Cultural practices are indicated in table 1. Each experiment was a randomized complete block design with 3 replications. Three herbicide treatments were used in experiment 1 in 2015-16 (Table 3) and four herbicide treatments were used in experiments 2 and 3 in 2016-17 (Tables 4 and 5). Herbicide treatments were applied by a backpack sprayer using $200 \mathrm{~L} \mathrm{ha}^{-1}$. Plots were $10 \mathrm{~m} \times 3$ $\mathrm{m}$. Rigid ryegrass was the most abundant weed in the experiments $\left(101,140\right.$, and 940 plants $\mathrm{m}^{-2}$, in experiments 1, 2, and 3, respectively). Several broadleaf weeds were found in the sites including burning nettle (Urtica urens), goosefoot (Chenopodium murale), sowthistle (Sonchus oleraceus), curly dock (Rumex pulcher), and spiny emex (Emex spinosa) (Table 2).

\subsection{Measurements}

Weeds were collected from one $0.50 \mathrm{~m} \times 0.50 \mathrm{~m}$ quadrat in each plot. They were clipped at ground level, bagged, and fresh weight measured 1, 2, and 3 months after treatment. Rigid ryegrass shoot biomasss reduction due to herbicide treatments was calculated as follows:

$\%$ rigid ryegrass shoot biomass reduction $=[$ (Rigid ryegrass shoot biomass in weedy plots - Rigid ryegrass shoot biomass in treated plots)/Rigid ryegrass shoot biomass in weedy plots $] \times 100$

At full maturity, wheat was harvested at ground level in an area of $1 \mathrm{~m}^{2}$ per plot. Wheat was threshed by a small combine and grain was cleaned and weighed. Wheat yield loss due to weed competition and yield increase due to herbicide use were calculated as follows:

$$
\begin{gathered}
\% \text { yield loss }=\left[\begin{array}{c}
{[\text { Wheat yield in weed-free plots }- \text { Wheat yield in weedy plots }) /} \\
\text { Wheat yield in weed-free plots }] \times 100
\end{array}\right. \\
\% \text { yield increase }=\left[\begin{array}{c}
{[\text { Wheat yield in weed }- \text { free plots }- \text { Wheat yield in weedy plots }) /} \\
\text { Wheat yield in weedy plots }] \times 100
\end{array}\right.
\end{gathered}
$$




\subsection{Statistical Analyses}

Measured variables (weed shoot fresh weight, wheat grain yield, and wheat straw yield) varied across experiments and cropping seasons, primarily due to differences in environmental conditions (irrigation, rainfall, soil type, crop rotation). Therefore, data analysis was performed for each experiment to determine the significance of the herbicide treatments. Weed biomass and wheat yield were subjected to the ANOVA using SAS (SAS Institute, Cary, NC, USA). Means were compared using the Fisher's protected LSD at $\mathrm{p}=0.05$.

\section{Results and Discussion}

\subsection{Weed Control}

Chlorotoluron $\left(2000 \mathrm{~g} \mathrm{ha}^{-1}\right)+$ isoxaben $\left(74.8 \mathrm{~g} \mathrm{ha}^{-1}\right)$, prosulfocarb $\left(4000 \mathrm{~g} \mathrm{ha}^{-1}\right)$, and prosulfocarb $\left(2000 \mathrm{~g} \mathrm{ha}^{-1}\right)+$ s-metolachlor $\left(300 \mathrm{~g} \mathrm{ha}^{-1}\right)$ reduced rigid ryegrass shoot biomass by $>90 \%$ during 3 months after treatments (MAT) (Tables 3 to 5). Pendimethalin $\left(1320 \mathrm{~g} \mathrm{ha}^{-1}\right)$ provided $83-99 \%$ rigid ryegrass control 1 to 3 MAT. Therefore, pre-emergence herbicides provided good to excellent control of rigid ryegrass that is resistant to 13 post-emergence herbicides having 2 modes of action (inhibition of ACCase and ALS). Thus, they would give acceptable season-long control. However, the few resistant ryegrass plants that were present in treated plots grew vigorously and produced seed.

Table 1. Characteristics of the 3 experiments conducted in the Doukkala irrigated perimeter in 2015-16 and 2016-17

\begin{tabular}{|c|c|c|c|}
\hline & Experiment 1 & Experiment 2 & Experiment 3 \\
\hline & $2015-16$ & $2016-17$ & $2016-17$ \\
\hline Location & Sidi Bennour & Tnine Gharbia & Sidi Bennour \\
\hline Crop & «Amal» Bread wheat & «Amal» Bread wheat & «Amal» Bread wheat \\
\hline Preceding crop & melon & sugarbeet & sugarbeet \\
\hline Tillage & $\begin{array}{l}1 \text { tandem disc }+ \text { manual fertilizer } \\
\text { spreading }+1 \text { tandem disc }+ \\
\text { Planting with a drill }\end{array}$ & $\begin{array}{l}1 \text { deep plow }+1 \text { tandem disc }+ \\
\text { manual fertilizer spreading }+1 \\
\text { tandem disc }+ \text { Planting with a drill }\end{array}$ & $\begin{array}{l}1 \text { deep plow }+1 \text { tandem disc }+ \\
\text { manual fertilizer spreading }+1 \\
\text { tandem disc }+ \text { Planting with a drill }\end{array}$ \\
\hline Date of planting & Nov 20, 2015 & Nov 15, 2016 & Nov 16, 2016 \\
\hline Date of crop emergence & Dec 1,2015 & Dec 1, 2016 & Dec 1,2016 \\
\hline Seeding rate & $200 \mathrm{~kg} \mathrm{ha}^{-1}$ & $200 \mathrm{~kg} \mathrm{ha}^{-1}$ & $200 \mathrm{~kg} \mathrm{ha}^{-1}$ \\
\hline \multirow[t]{2}{*}{ Fertilizer at planting } & $200 \mathrm{~kg} \mathrm{ha}^{-1}$ & $300 \mathrm{~kg} \mathrm{ha}^{-1}$ & $300 \mathrm{~kg} \mathrm{ha}^{-1}$ \\
\hline & $15-15-15$ & $15-15-15$ & $15-15-15$ \\
\hline Top dressing nitrogen & $\begin{array}{l}100 \mathrm{~kg} \mathrm{ha}^{-1} \text { ammonium nitrate } \\
33 \% \text { at tillering }+100 \mathrm{~kg} \mathrm{ha}{ }^{-1} \\
\text { ammonium nitrate } 33 \% \text { at jointing }\end{array}$ & $\begin{array}{l}100 \mathrm{~kg} \mathrm{ha}^{-1} \text { ammonium nitrate } \\
33 \% \text { at tillering }+100 \mathrm{~kg} \mathrm{ha}{ }^{-1} \\
\text { ammonium nitrate } 33 \% \text { at jointing }\end{array}$ & $\begin{array}{l}100 \mathrm{~kg} \mathrm{ha}^{-1} \text { ammonium nitrate } \\
33 \% \text { at tillering }+100 \mathrm{~kg} \mathrm{ha}^{-1} \\
\text { ammonium nitrate } 33 \% \text { at jointing }\end{array}$ \\
\hline Irrigation system & Flood irrigation & Sprinkle irrigation & Flood irrigation \\
\hline Fungicides & $\begin{array}{l}\text { Epoxiconazole }\left(125 \mathrm{~g} \quad \mathrm{ha}^{-1}\right) \\
\text { followed by propiconazole }(125 \mathrm{~g} \\
\left.\mathrm{ha}^{-1}\right)\end{array}$ & $\begin{array}{l}\text { Epoxiconazole }\left(\begin{array}{lll}125 & \mathrm{~g} & \mathrm{ha}^{-1}\end{array}\right) \\
\text { followed by propiconazole }(125 \mathrm{~g} \\
\left.\mathrm{ha}^{-1}\right)\end{array}$ & $\begin{array}{l}\text { Epoxiconazole }\left(\begin{array}{lll}125 & \mathrm{~g} & \mathrm{ha}^{-1}\end{array}\right) \\
\text { followed by propiconazole }(125 \mathrm{~g} \\
\left.\mathrm{ha}^{-1}\right)\end{array}$ \\
\hline $\begin{array}{l}\text { Date of spraying weed } \\
\text { control experiments }\end{array}$ & $\begin{array}{l}\text { Nov 25, } 2015 \text { after planting before } \\
\text { emergence }\end{array}$ & $\begin{array}{l}\text { Nov 22, } 2016 \text { after planting before } \\
\text { emergence }\end{array}$ & $\begin{array}{l}\text { Nov 26, } 2016 \text { after planting before } \\
\text { emergence }\end{array}$ \\
\hline
\end{tabular}


Table 2. Weed density in plants $\mathrm{m}^{-2}$ after wheat emergence in the untreated plots in 3 experiments conducted in the Doukkala irrigated perimeter, Morocco, in 2015-16 and 2016-17

\begin{tabular}{llll}
\hline \multirow{2}{*}{ Weed species } & $2015-16$ & $2016-17$ & $2016-17$ \\
\cline { 2 - 4 } Rigid ryegrass (Lolium rigidum) & Experiment 1 & Experiment 2 & Experiment 3 \\
Burning nettle (Urtica urens) & 101 & 140 & 940 \\
Goosefoot (Chenopodium murale) & 332 & 4 & 0 \\
Curly dock (Rumex pulcher) & 8 & 0 & 0 \\
Spiny emex (Emex spinosa) & 4 & 0 & 0 \\
Chickweed (Stellaria media) & 1 & 0 & 0 \\
Catchfly (Silene gallica) & 0 & 0 & 0 \\
Others & 0 & 0 & 0 \\
Total density (plants $\mathrm{m}^{-2}$ ) & 12 & 2 & 0 \\
\hline
\end{tabular}

In general, maximum weed densities and weed fresh weights were recorded in the weedy plots while minimum weed densities and fresh weights were observed in plots treated with pre-emergence herbicides. In Australia, Boutsalis et al. (2014) and Kleemann et al. (2014) found that prosulfocarb at $2000 \mathrm{~g} \mathrm{ha}^{-1}+\mathrm{s}$-metolachlor at 300 $\mathrm{g} \mathrm{ha}^{-1}$ provided $>64 \%$ control of herbicide resistant rigid ryegrass. Pendimethalin at $720 \mathrm{~g} \mathrm{ha}^{-1}$ provided $75 \%$ control of herbicide resistant rigid ryegrass (Chauhan et al., 2007).

\subsection{Wheat Injury}

The four herbicide treatments [i) chlorotoluron $\left(2000 \mathrm{~g} \mathrm{ha}^{-1}\right)+$ isoxaben $\left(74.8 \mathrm{~g} \mathrm{ha}^{-1}\right)$, ii) prosulfocarb $(4000 \mathrm{~g}$ $\left.\mathrm{ha}^{-1}\right)$, iii) prosulfocarb $\left(2000 \mathrm{~g} \mathrm{ha}^{-1}\right)+\mathrm{s}$-metolachlor $\left(300 \mathrm{~g} \mathrm{ha}^{-1}\right)$, and iv) pendimethalin $\left.\left(1320 \mathrm{~g} \mathrm{ha}^{-1}\right)\right]$ reduced wheat emergence and density in both experiments in 2016-17 (data not shown). However, none of the herbicide treatments visibly injured wheat in 2015-16. It is highly possible that wheat injury was due to heavy rain (about $100 \mathrm{~mm}$ ) after herbicide treatments and before crop emergence. Kleemann et al. (2014) found that prosulfocarb $\left(2000 \mathrm{~g} \mathrm{ha}^{-1}\right)+\mathrm{s}$-metolachlor $\left(300 \mathrm{~g} \mathrm{ha}^{-1}\right)$ reduced wheat density 25 to $57 \%$ when planting was associated with heavy post-planting rainfall. Such rainfall events after planting could cause movement of the herbicides into the furrow. The risk of wheat injury from preemergence applications could be lessened if planting or preemergence herbicide applications are postponed when heavy rain (and/or irrigation) is forecast. Prosulfocarb + s-metolachlor occasionally resulted in a significant reduction in wheat emergence but not crop yield (Boutsalis et al., 2014).

\subsection{Wheat Grain Yields}

Although reductions in wheat plant density due to injury from all herbicides, there was still a significant yield increase relative to the nontreated plots as a result of the effective control. These results suggest that wheat can compensate for early reduction in wheat density, the crop was able to fully recover and did not suffer any yield penalty. Thus, no significant differences were observed between yields obtained in various treated plots. Yield variations between experiments and years were probably due to different preceding crops and irregular durations between irrigations. Grain yields in sprayed plots ranged from 6.6 to $9.8 \mathrm{t} \mathrm{ha}^{-1}, 4.4$ to $7.4 \mathrm{t} \mathrm{ha}^{-1}, 7.3$ to $8.9 \mathrm{t} \mathrm{ha}^{-1}$, in experiments 1 to 3 , respectively (Tables 3 to 5).

Using the highest yields obtained in treated plots, potential grain yield increases due to weed control were 100 to $197 \%$ in experiment 1 (2015-16), 126 to 174\% in experiment 2 (2016-17), and 92 to 134\% in experiment 3 (2016-17), compared to the yields observed in nontreated plots (Tables 3 to 5). Weed control improved grain yields through better utilization of available resources like water, fertilizer, sunlight, and space. Other appropriate practices that could have increased grain yield were November planting, certified seeds, disease control with two fungicide treatments, and irrigation (Tanji et al., 2017). Kleemann et al. (2014) found that the highest wheat grain yields were observed in plots where rigid ryegrass resistant to postemergence herbicides was effectively controlled with preemergence herbicides such as prosulfocarb $\left(2000 \mathrm{~g} \mathrm{~h}^{-1}\right)+\mathrm{s}$-metolachlor $(300 \mathrm{~g}$ $\left.\mathrm{ha}^{-1}\right)$.

In untreated plots, grain yields were low compared to treated plots (Tables 3 to 5). Potential yield losses due to weed competition throughout the growing season were 66,63 , and 57\% compared to the highest yields observed in treated plots in experiments 1,2 , and 3, respectively. Rigid ryegrass and broadleaf weeds left in the nontreated plots appeared to cause significant crop production losses; hence, herbicide selection should be based on 
knowledge of weed species present within the weed flora. This is consistent with previous research that has emphasized the potential for irrigated bread wheat yield loss due to rigid ryegrass competition (Tanji et al., 1997).

Table 3. Rigid ryegrass shoot fresh biomass $\left(\mathrm{g} \mathrm{m}^{-2}\right)$ and wheat yield $\left(\mathrm{t} \mathrm{ha}^{-1}\right)$ in experiment 1 in the Doukkala irrigated perimeter, Morocco, in 2015-16

\begin{tabular}{|c|c|c|c|c|c|c|}
\hline \multirow{2}{*}{ Herbicide $\left(\right.$ rate ha $\left.{ }^{-1}\right)$} & & \multicolumn{3}{|c|}{ Shoot fresh biomass of rigid ryegrass $\left(\mathrm{g} \mathrm{m}^{-2}\right)$} & \multicolumn{2}{|c|}{ Wheat yield $\left(\mathrm{t} \mathrm{ha}^{-1}\right)$} \\
\hline & & $1 \mathrm{MAT}$ & $2 \mathrm{MAT}$ & 3 MAT & Grain & Straw \\
\hline Chlorotoluron $(2000 \mathrm{~g})+$ Isoxaben $(74.8 \mathrm{~g})$ & AUBAINE (4 L) & 7 & 213 & 53 & 9.8 & 15.4 \\
\hline Prosulfocarb (4000 g) & BOXER $(5 \mathrm{~L})$ & 13 & 93 & 607 & 6.6 & 12.1 \\
\hline Pendimethalin $(1320 \mathrm{~g})$ & PROWL (4 L) & 80 & 260 & 167 & 7.2 & 11.4 \\
\hline Untreated check & & 460 & 2307 & 6113 & 3.3 & 5.6 \\
\hline $\operatorname{LSD}(0.05)$ & & 256 & 1362 & 2241 & 1.6 & 3.1 \\
\hline
\end{tabular}

Note. MAT: month after treatment; Prosulfocarb (2000 g) + s-metolachlor $(300 \mathrm{~g})$ was not evaluated in this experiment.

Table 4. Rigid ryegrass shoot fresh biomass $\left(\mathrm{g} \mathrm{m}^{-2}\right)$ and wheat yield $\left(\mathrm{t} \mathrm{ha}^{-1}\right)$ in experiment 2 in the Doukkala irrigated perimeter, Morocco, in 2016-17

\begin{tabular}{|c|c|c|c|c|c|c|}
\hline \multirow[t]{2}{*}{ Herbicide (rate ha ${ }^{-1}$ ) } & & \multicolumn{3}{|c|}{$\begin{array}{l}\text { Shoot fresh biomass of rigid ryegrass } \\
\qquad\left(\mathrm{g} \mathrm{m}^{-2}\right)\end{array}$} & \multicolumn{2}{|c|}{ Wheat yield $\left(\mathrm{t} \mathrm{ha}^{-1}\right)$} \\
\hline & & $1 \mathrm{MAT}$ & $2 \mathrm{MAT}$ & $3 \mathrm{MAT}$ & Grain & Straw \\
\hline Chlorotoluron $(2000 \mathrm{~g})+$ Isoxaben $(74.8 \mathrm{~g})$ & AUBAINE (4 L) & 7 & 180 & 120 & 6.8 & 9.6 \\
\hline Prosulfocarb (4000 g) & $\operatorname{BOXER}(5 \mathrm{~L})$ & 4 & 40 & 700 & 6.1 & 10.6 \\
\hline Prosulfocarb (2000 g) + s-metolachlor $(300 \mathrm{~g})$ & BOXER GOLD (2.5 L) & 3 & 0 & 513 & 7.4 & 15.8 \\
\hline Pendimethalin (1320 g) & PROWL (4 L) & 17 & 727 & 1780 & 4.4 & 10.8 \\
\hline Untreated check & & 300 & 4793 & 10340 & 2.7 & 4.4 \\
\hline $\operatorname{LSD}(0.05)$ & & 30 & 1055 & 2244 & 2.3 & 5.9 \\
\hline
\end{tabular}

Note. MAT: month after treatment.

Table 5. Rigid ryegrass shoot fresh biomass $\left(\mathrm{g} \mathrm{m}^{-2}\right)$ and wheat yield $\left(\mathrm{t} \mathrm{ha}^{-1}\right)$ in experiment 3 in the Doukkala irrigated perimeter, Morocco, in 2016-17

\begin{tabular}{|c|c|c|c|c|c|c|}
\hline \multirow[t]{2}{*}{ Herbicide $\left(\right.$ rate ha ${ }^{-1}$ ) } & & \multicolumn{3}{|c|}{$\begin{array}{l}\text { Shoot fresh biomass of rigid ryegrass } \\
\qquad\left(\mathrm{g} \mathrm{m}^{-2}\right)\end{array}$} & \multicolumn{2}{|c|}{ Wheat yield $\left(\mathrm{t} \mathrm{ha}^{-1}\right)$} \\
\hline & & $1 \mathrm{MAT}$ & 2 MAT & 3 MAT & Grain & Straw \\
\hline Chlorotoluron $(2000 \mathrm{~g})+$ Isoxaben $(74.8 \mathrm{~g})$ & AUBAINE (4 L) & 0 & 0 & 40 & 8.9 & 12.5 \\
\hline Prosulfocarb (4000 g) & $\operatorname{BOXER}(5 \mathrm{~L})$ & 1 & 93 & 147 & 7.3 & 10.5 \\
\hline Prosulfocarb $(2000 \mathrm{~g})+\mathrm{s}-$ metolachlor $(300 \mathrm{~g})$ & BOXER GOLD (2.5 L) & 1 & 20 & 187 & 8.4 & 14.5 \\
\hline Pendimethalin (1320 g) & PROWL (4 L) & 1 & 107 & 87 & 7.5 & 10.1 \\
\hline Untreated check & & 933 & 2107 & 4280 & 3.8 & 7.9 \\
\hline $\operatorname{LSD}(0.05)$ & & NS & 469 & 1387 & 1.1 & 5.4 \\
\hline
\end{tabular}

Note. MAT: month after treatment.

\subsection{Wheat Straw Yields}

In the 3 experiments, higher wheat straw yields were obtained in treated plots compared to untreated plots: 11.4 to $15.4,9.6$ to 15.8 , and 10.1 to $14.5 \mathrm{t} \mathrm{ha}^{-1}$ in the 3 experiments, respectively (Tables 3 and 5). However, the lowest wheat straw yields $\left(5.6,4.4\right.$, and $7.9 \mathrm{t} \mathrm{ha}^{-1}$, respectively) were observed in untreated plots which showed severe competition of high stands of rigid ryegrass $\left(101,140\right.$, and 940 plants $\mathrm{m}^{-2}$, respectively) with bread wheat. Using the highest straw yields observed in treated plots, potential yield increases due to weed control were 104 to $175 \%, 118$ to $259 \%$, and 28 to $84 \%$, compared to wheat straw yields measured in nontreated plots in experiments 1 to 3, respectively. Potential straw yield losses due to weed competition were 64, 72, and 46\% 
compared to the highest straw yields observed in treated plots in experiments 1,2 , and 3, respectively. Previous research showed that weed control with herbicides improved wheat straw yields through better utilization of water and other resources (Tanji et al., 2017).

\section{Conclusion}

The results of this study indicate that excellent to good control of rigid ryegrass that is resistant to postemergence herbicides (essentially cyclohexanediones and aryloxyphenoxypropionates) can be achieved by the application of preemergence herbicide treatments such as chlorotoluron $\left(2000 \mathrm{~g} \mathrm{ha}^{-1}\right)+$ isoxaben $\left(74.8 \mathrm{~g} \mathrm{ha}^{-1}\right)$, prosulfocarb $\left(4000 \mathrm{~g} \mathrm{ha}^{-1}\right)$, prosulfocarb $\left(2000 \mathrm{~g} \mathrm{ha}^{-1}\right)+\mathrm{s}$-metolachlor $\left(300 \mathrm{~g} \mathrm{ha}^{-1}\right)$, or pendimethalin $\left(1320 \mathrm{~g} \mathrm{ha}^{-1}\right)$. Although preemergence herbicides provide effective new options for the selective control of postemergence herbicide resistant rigid ryegrass, preemergence herbicides need to be used by wheat growers as part of an integrated weed management program. Further research is needed to explore ways to avoid wheat injury, occasionally caused by heavy rain or irrigation after preemergence herbicide application and before crop emergence.

\section{Acknowledgements}

This research work was conducted under the project "Enhancing Food Security in Arab Countries-Phase II". The authors would like to thank the Arab Fund for Economic and Social Development (AFESD), the Kuwait Fund for Arab Economic Development (KFAED), the Bill and Melinda Gates Foundation (BMFG) and the OPEC Fund for International Development (OFID) for their financial support and ICARDA for facilitating this study. Chlorotoluron + isoxaben was provided by Dow Agrosciences. Prosulfocarb and prosulfocarb $+\mathrm{s}$-metolachlor were provided by Syngenta.

\section{References}

Bararpour, M. T., Norsworthy, J. K., Burgos, N. R., Korres, N. E., \& Gbur, E. E. (2017). Identification and biological characteristics of ryegrass (Lolium spp.) accessions in Arkansas. Weed Science, 65(3), 350-360. https://doi.org/10.1017/wsc.2016.28

Baye, Y. (2014). Le ray grass (Lolium rigidum Gaud.) résistant aux herbicides "fops" dans la région du Tadla: état d'infestation et gestion intégrée. Proceedings du Neuvième Congrès de l'Association Marocaine de la Protection des Plantes (AMPP), Rabat (pp. 243-253).

Boutsalis, P., Gill, G. S., \& Preston, C. (2014). Control of rigid ryegrass in Australian wheat production with pyroxasulfone. Weed Technology, 28(2), 332-339. https://doi.org/10.1614/WT-D-13-00094.1

Castellanos-Frias, E., Garcia de Leon, D., Bastida, F., \& Gonzalez-Andujar, J. L. (2016). Predicting global geographical distribution of Lolium rigidum (rigid ryegrass) under climate change. The Journal of Agricultural Science, 154(5), 755-764. https://doi.org/10.1017/S0021859615000799

Chauhan, B. S., Gill, G. S., \& Preston, C. (2007). Effect of seeding systems and dinitroaniline herbicides on emergence and control of rigid ryegrass (Lolium rigidum) in wheat. Weed Technology, 21(1), 53-58. https://doi.org/10.1614/WT-06-044.1

Délye, C. (2005). Weed resistance to acetyl coenzyme A carboxylase inhibitors: An update. Weed Science, 53(5), 728-746. https://doi.org/10.1614/WS-04-203R.1

El Aimani, A., \& Tanji, A. (2016). Prosulfocarbe : une nouvelle solution pour la gestion de la résistance du ray grass aux herbicides dans le blé. Neuvième congrès de l'Association Marocaine des Plantes (AMPP), Rabat (pp. 243-253).

Han, H., Yu, Q., Owen, M. J., Cawthray, G. R., \& Powles, S. B. (2016). Widespread occurrence of both metabolic and target-site herbicide resistance mechanisms in Lolium rigidum populations. Pest Management Science, 72(2), 255-263. https://doi.org/10.1002/ps.3995

Heap, I. (2018). The international survey of herbicide resistant weeds. Retrieved from http://www.weed science.com

Kleemann, S. G. L., Preston, C., \& Gill, G. S. (2014). Influence of seeding system disturbance on preplant incorporated herbicide control of rigid ryegrass (Lolium rigidum) in wheat in Southern Australia. Weed Technology, 28(2), 323-331. https://doi.org/10.1614/WT-D-13-00065.1

Loureiro, I., Escorial, C., Hernández Plaza, E., González Andújar, J. L., \& Chueca, M. C. (2017). Current status in herbicide resistance in Lolium rigidum in winter cereal fields in Spain: Evolution of resistance 12 years after. Crop Protection, 102(1), 10-18. https://doi.org/10.1016/j.cropro.2017.08.001 
Malone, J. M., Boutsalis, P., Baker, J., \& Preston, C. (2014). Distribution of herbicide-resistant acetyl-coenzyme A carboxylase alleles in Lolium rigidum across grain cropping areas of South Australia. Weed Research, 54(1), 78-86. https://doi.org/10.1111/wre.12050

Nègre, M., Passarella, I., Boursier, C., Mozzetti, C., \& Gennari, M. (2006). Evaluation of the bioavailability of the herbicide prosulfocarb through adsorption on soils and model soil colloids, and through a simple bioassay. Pest Management Science, 62(10), 957-964. https://doi.org/10.1002/ps.1264

Preston, C., Kleemann, S. G. L., Noack, S., Hooper, P., \& Gill, G. S. (2017). Using time of sowing of wheat and pre-emergent herbicides to control annual ryegrass (Lolium rigidum). Proceedings of the 18th Australian Society of Agronomy Conference, Ballarat, Australia (pp. 1-4).

Saini, R. K., Malone, J., Preston, C., \& Gill, G. (2015). Target enzyme-based resistance to clethodim in Lolium rigidum populations in Australia. Weed Science, 63(4), 946-953. https://doi.org/10.1614/WS-D-14-00176.1

Scarabel, L., Panozzo, S., Varotto, S., \& Sattin, M. (2011). Allelic variation of the ACCase gene and response to ACCase-inhibiting herbicides in pinoxaden-resistant Lolium spp. Pest Management Science, 67(8), 932-941. https://doi.org/10.1002/ps.2133

Tanji, A. (2009). Efficacité des herbicides sur l'ivraie raide (Lolium rigidum). Actes du symposium international AGRUMED «Durabilité des systèmes de culture en zone méditerranéenne, gestion des ressources en eau et en sol», Rabat (pp. 380-383).

Tanji, A. (2011). Adventices résistantes aux herbicides au Maroc (p. 30). Troisième Congrès international sur l'amélioration de la production agricole (APA3), Settat.

Tanji, A. (2013). Betterave à sucre: La cléthodime est encore efficace sur le ray grass résistant aux herbicides. Agriculture du Maghreb, 64, 102-104.

Tanji, A., Baye, B., \& Boutfirass, M. (2017). Evaluating postemergence herbicides for broadleaf weed control in irrigated bread wheat (Triticum aestivum L.). Journal of Experimental Biology and Agricultural Sciences, 5(5), 614-622. http://dx.doi.org/10.18006/2017.5(5).614.622

Tanji, A., Merimi, Z., Laftah, M., Ezzaari, A., \& Jabbari, A. (2012). Gestion intégrée de l'ivraie raide (Lolium rigidum) résistante aux herbicides. Proceedings du huitième Congrès de l'Association Marocaine de Protection des Plantes (AMPP), Rabat (pp. 421-433).

Tanji, A., Zimdahl, R. L., \& Westra, P. (1997). The competitive ability of wheat (Triticum aestivum) compared to rigid ryegrass (Lolium rigidum) and cowcockle (Vaccaria hispanica). Weed Science, 45(4), 481-487. https://doi.org/10.1017/S0043174500088706

Yu, Q., \& Powles, S. B. (2014). Resistance to AHAS inhibitor herbicides: Current understanding. Pesticide Management Science, 70(9), 1340-1350. https://doi.org/10.1002/ps.3710

\section{Copyrights}

Copyright for this article is retained by the author(s), with first publication rights granted to the journal.

This is an open-access article distributed under the terms and conditions of the Creative Commons Attribution license (http://creativecommons.org/licenses/by/4.0/). 